\title{
INTEGRATED MARINE MONITORING FOR DRILLING DISCHARGES UNDER MESOTIDAL FORCING
}

\author{
O. Makarynskyy, D. Makarynska \\ Metocean Dynamic Solutions, 9 Seale Street, Fannie Bay, 0820 NT, Australia, \\ makarynskyy@outlook.com, https://orcid.org/0000-0002-0505-5882
}

There is a range of hydrocarbon exploration and extraction industrial project activities taking place on the North West Shelf of the Australian Continent. The shelf is a diverse and important marine ecosystem, with a number of globally significant shallow coral reefs and marine protected areas, which are vital for survival of threatened and protected species.

Some of the mentioned exploration and extraction activities, such as offshore drilling, may be permitted within few kilometres away from sensitive habitats extant near a project resource extraction area. The habitats may in some cases be presented by submerged shoal ecosystems of high biodiversity and thus high environmental/ecological value, due to the presence of either or both benthic biota and fish assemblages.

As part of an environmental assessment program for the industrial activities, some of the offshore exploration operators examine the effects of drilling discharges on the marine ambience. This study describes such an assessment. For the assessment, a novel integrated marine monitoring approach was conceptually designed; the program was then executed in the field using bottommounted equipment and a remotely operated underwater vehicle with sensors mounted on it.

This study focuses on assessing the wind conditions in the project area, sea level and current velocities, in situ water temperature, salinity, turbidity and acoustic echo intensity, over several stages of the drilling operations while the drilling cuttings and muds were discharged into the water column.

The collected during the austral autumn months of April and May winds showed prevailing east-southeaserlies, which is aligned well with the general understanding of wind climatology of the area. Importantly, stronger than usual winds may have a defining impact on current speeds and directions, with the current speeds enhanced by such winds. On these occasions the water transporting a discharge material may pushed towards the sensitive habitat present in the area. Normally though the hydrodynamics in the project area are dominated by semi-diurnal tides.

Both vertical current velocity and water temperature distributions indicated the presence of three layers within the water column over the project site. The vertical distribution of water salinity was rather homogenous throughout the entire water column.

The monitored by an optical instrument turbidity and acoustic echo intensity from an ADCP (acoustic Doppler current profiler) showed that tracing discharge plumes with a remotely operated underwater vehicle is a viable technique, which could be implemented at other locations. Such independent parameters though need a thorough cross-calibration and inter-validation for the results to be fully understood.

Key words: drilling, cuttings, muds, turbidity, plume, remotely operated underwater vehicle, continental shelf, water column layering, acoustic Doppler current profiler, echo intensity

\section{INTRODUCTION}

There is a range of hydrocarbon exploration and extraction industrial project activities taking place on the North West Shelf (NWS) of the Australian Continent. Meanwhile, the NWS is a place where diverse and globally important marine ecosystems exist. There are such ecologically significant bathymetric and topographic features as Ashmore, Scott and Seringapatam Reefs, and Rowley Shoals. There also are a number of marine protected and biologically important areas for benthic and pe- lagic flora and fauna, including such threatened megafauna species as whale sharks, pygmy blue whales and flatback turtles. Recognised key ecological features of the NWS also include the Ancient Coastline at $125 \mathrm{~m}$ depth and numerous banks and mounds that support diverse reef communities (see e.g. $[1,3]$ ).

Notably, some of the industrial activities on the NWS, such as offshore exploration drilling, may be permitted within few kilometres away from sensitive habitats extant in the area. The habitats may in some cases be presented by submerged shoal 
ecosystems of high biodiversity and thus high environmental / ecological value, due to the presence of either or both benthic biota and fish assemblages.

The sensitivity of such habitats to anthropogenic impacts is due to their remoteness from any populated areas, tens and hundreds of kilometres away from the continental coastline. Therefore, such common in the nearshore areas stressors as degraded water quality and high turbidity (frequently detected near coastal towns and cities) are not normally affecting the offshore habitats; since the abundance of species and diversity of marine ecosystems staying virtually undisturbed by anthropogenic activities for prolonged periods of time.

As part of the risk assessment program for the industrial activities, some of the offshore exploration operators examine the effects of drilling discharges on the marine ambience. This study describes such an assessment. For the assessment, a novel integrated marine monitoring approach was conceptually designed and then executed in the field using a number of bottom-mounted and water column positioned sensors and oceanographic instruments. To collect in situ, water column data, such cutting edge technology as a remotely operated underwater vehicle (ROV) was used with a number of oceanographic and water quality sensors mounted on it.

The objective of this field monitoring program was to assess and understand fates of plumes of drilling cuttings and muds, and probable environmental impacts from such plumes. This would allow reducing uncertainty and in turn improving management of drilling campaigns around/near sensitive environments, and also assessing any ecosystem changes associated with drilling activities.

The present study describes the undertaken field program and desktop assessment components, and analyses the collected marine and water quality data.

\section{PROJECT SITE LOCATION}

The drilling project area was located approximately $120 \mathrm{~km}$ offshore off the Pilbara Coast of Western Australia, on the NWS of the Australian continent. The precise location of the operations may not be disclosed due to the project commercial sensitivities.

The drilling site was located in the water approximately $80 \mathrm{~m}$ deep. The site was at a distance of approximately $5 \mathrm{~km}$ from the closest submerged reef system, which rises from around $120 \mathrm{~m}$ depth up to $20 \mathrm{~m}$ depth at its shallowest point. The reef is a unique bathymetric feature, which supports a number of diverse shallow ecosystems in the oth- erwise homogenous sedimentary continental shelf setting.

\section{EQUIPMENT AND COLLECTED DATA}

There were three sets of equipment used to collect the metocean data.

There was a weather monitoring station installed on the mobile offshore drilling platform. The collected wind data were accordingly processed and converted to $10 \mathrm{~m}$ above water surface before being used in further calculations.

There was a set of instruments consisting of an acoustic Doppler current profiler (a $100 \mathrm{kHz}$ Teledyne RDI Workhorse ADCP) and a pressure gauge mounted on a frame and deployed at the seabed, $200 \mathrm{~m}$ north-west from the drilling site. The location for the frame was selected based on the worst case scenario for the drilling discharge plumes moving in the direction of the sensitive habitats.

There also was a set of oceanographic and water quality sensors mounted on the ROV. The sensors were collecting registrations of the following marine environmental parameters;

- In situ water temperature and salinity,

- In situ turbidity,

- Vertical transects of acoustic echo intensity collected by a $300 \mathrm{kHz}$ Teledyne RDI Workhorse ADCP.

The turbid plumes from different types of discharge operations are notoriously patchy and difficult to detect and follow in the field (see e.g. [6-7]). Therefore the purpose of the instrumentation being mounted on the ROV specifically for this field program was to visually assess the in situ water turbidity and delineate the turbid discharge plumes, and then follow the plumes when detected. The sensors operated remotely would in this case collect data inside such plumes, which otherwise would not be easily achievable (see e.g. [9]).

All the itemised marine environmental parameters were monitored over the period of drilling operations in progress, in April-May 2017. For the purposes of the present study, the collected data were processed and visualised; an analysis and respective discussion are presented below.

\section{DATA ANALYSIS}

\subsection{Data presentation}

In the present study, data analysis is based on wind/current rose and time series plots, as well as box plots.

The rose plots depict compass points, data per- 
centages and data ranges within the provided colour scale.

Time series plots present values at specific times, over the deployment periods.

The box plots provide a visualization of summary statistics and contain the following features:

- the tops and bottoms of each "box" are the 25th and 75th percentiles of the data, respectively; the distances between the tops and bottoms are the interquartile ranges

- the line in the middle of each box is the median; if the median is not centred in the box, it shows sample skewness

- the whiskers are lines extending above and below each box; whiskers are drawn from the ends of the interquartile ranges to the furthest observations within the whisker length (the adjacent values)

- observations beyond the whisker length are outliers marked with red + signs; an outlier is a value that is more than 1.5 times the interquartile range away from the top or bottom of the box.

\subsection{Wind monitoring}

Wind is an important meteorological parameter due to its contribution to current generation and water mixing $[6,9,11]$. Figure 1 and Figure 2 respectively exhibit wind rose and box plots of the wind records collected at the project location in April-May 2017.

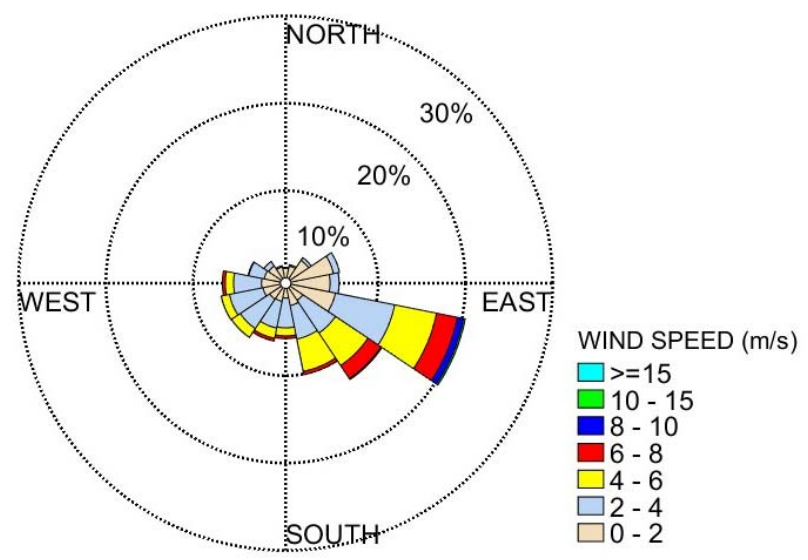

Figure 1 - Wind rose for winds recorded over monitoring period

An analysis of the figures suggests that the winds were from various directions, with up to $40-45 \%$ of winds from east-southeast through to southsoutheast. There were winds with up to $12 \mathrm{~m} / \mathrm{s}$ speeds observed from east-southeast and south-east. Such winds are typically observed in the area during the months of April and May.

Figure 3 presents wind speed and direction time series from the same location for the period of oceanographic monitoring. The plots suggest that there were several instances when $10-12 \mathrm{~m} / \mathrm{s}$ winds from the south-easterly quadrant lasted for up to a day, particularly over the period of 27-29 April 2017. To understand any implications onto transport processes, these events will be considered in combination with the monitored current speeds and directions in section 4.4.



Figure 2 - Box plot for winds recorded over monitoring period

\subsection{Sea level}

The dominant forcing for ocean currents in the project area is barotropic tides, i.e. water motion occurs in unison over the entire water column and is chiefly caused by the gravitational attraction of the Moon and the Sun.

There was a pressure gauge deployed at the seabed stand; Figure 4 presents a time series plot of depth logs from the gauge. An analysis of the figure suggests that the tides at the deployment site are semi-diurnal. Over the deployment duration, there were periods of both neap and spring tides, with the maximal tidal range of $3.1 \mathrm{~m}$, which is in line with general understanding of the tidal conditions in the area $[1,10]$.

\subsection{Current velocities}

Ocean currents are generally the major factor responsible for sediment transport in the open ocean conditions. The acoustic transducer of the ADCP was positioned $2.0 \mathrm{~m}$ above seabed. Due to the instrument bin size set to $2.0 \mathrm{~m}$, the first bin (referred to as Bin 1 and so on thereafter) was located $4.2 \mathrm{~m}$ above the transducer height. A Bin is a threedimensional cell (volume) of water in which echo 

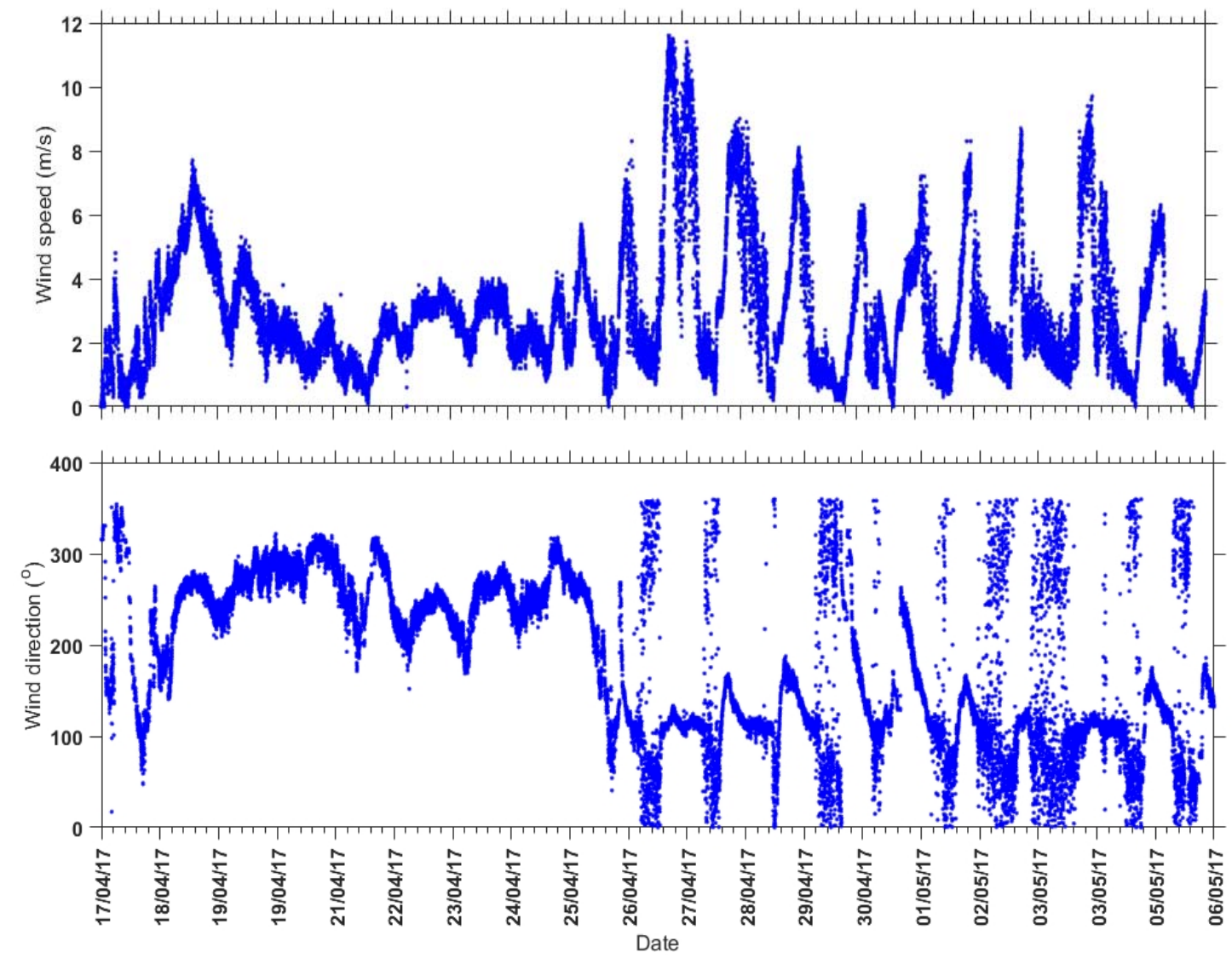

Figure 3 - Time series plots of wind speed (top panel) and direction (bottom panel) over monitoring period

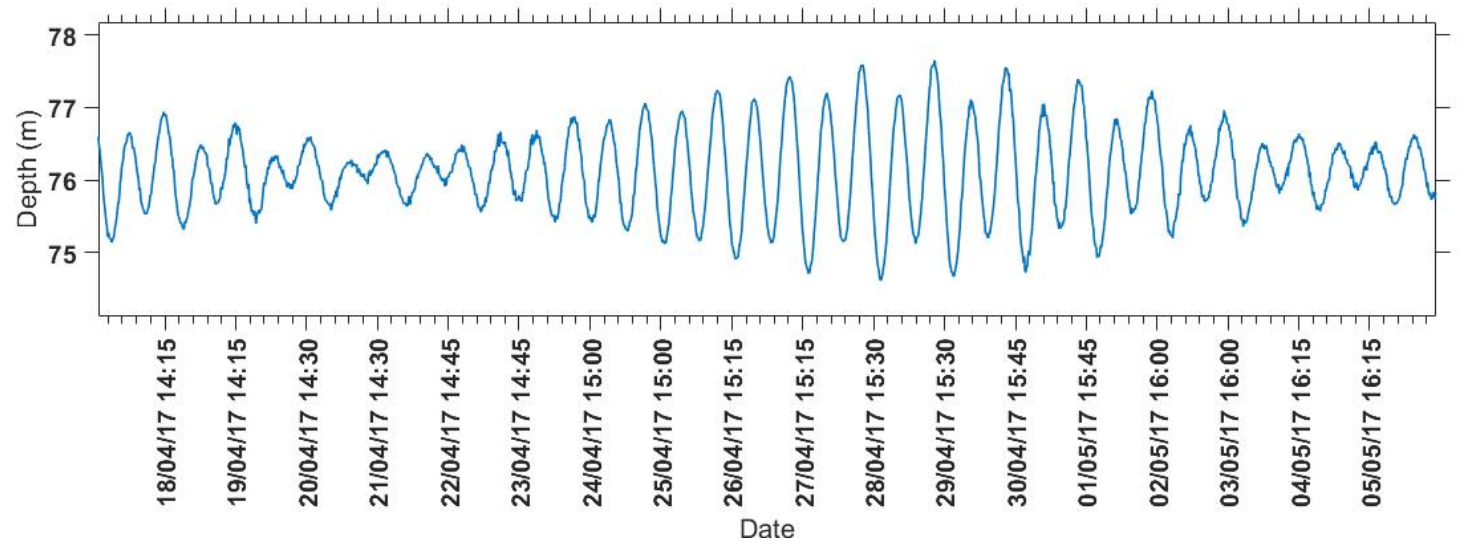

Figure 4 - Time series plots of sea level record over monitoring period

intensity and current velocity are acoustically assessed / measured by an ADCP.

An important parameter to analyse when considering an ADCP performance, is acoustic echo intensity, which is an indicator of the strength of the returned signal. Logs of acoustic echo intensity over the campaign period are presented in Figure 5.

An analysis of the data presented in Figure 5 suggests that there were strong acoustic returns centred on bins $36-37$, which were located 72.0$74.0 \mathrm{~m}$ above the transducer height. Adding the transducer height above seabed $(2.0 \mathrm{~m})$ to the distance to the first bin $(4.2 \mathrm{~m})$ and to the range of strong returns $(72.0 \mathrm{~m})$ gives the total depth of around $78 \mathrm{~m}$, which was the depth at the deployment site. The bins demonstrating high echo intensity values are therefore located in the layer of reflection of the acoustic signal from the water-air boundary. There usually are one-two bins, which 


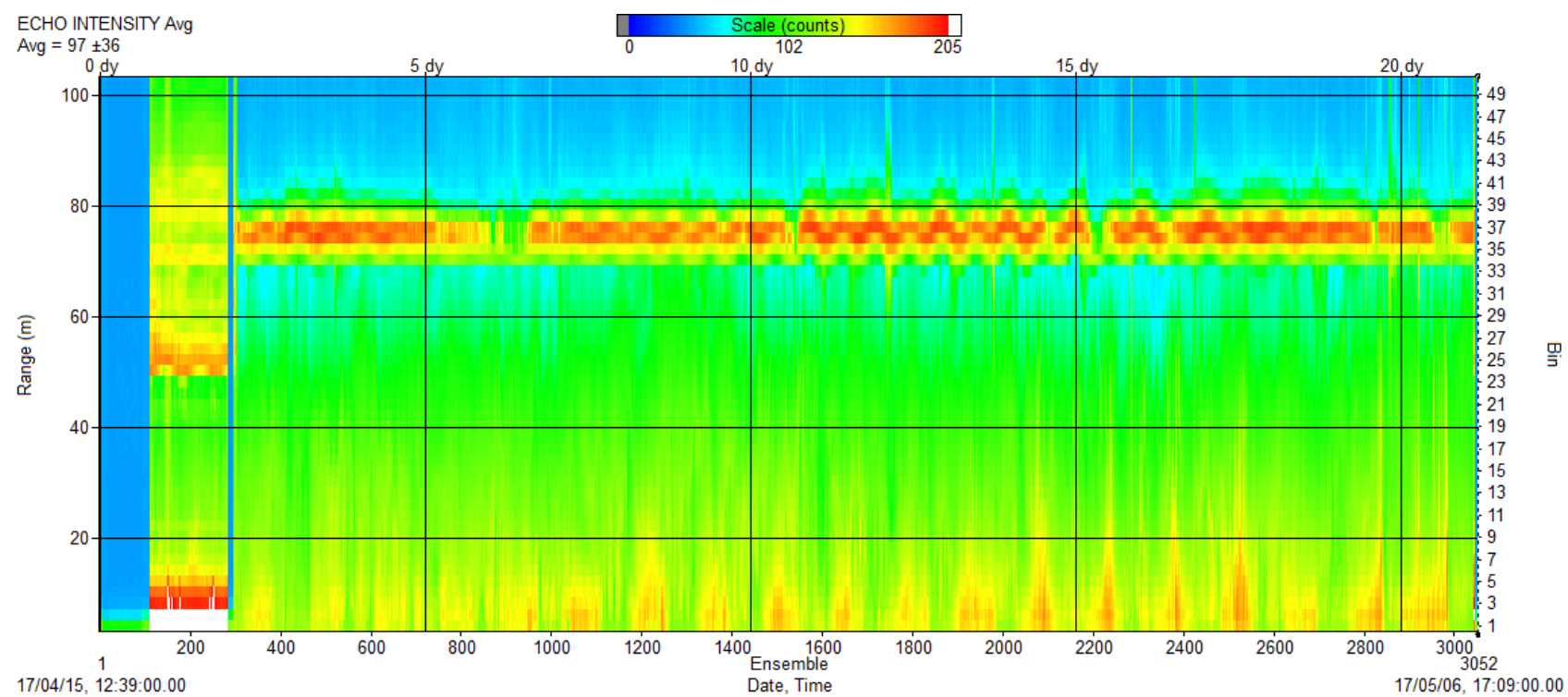

Figure 5 - Acoustic echo intensity over monitoring period

may be affected by the high intensity of the reflection from a boundary; the data from those bins may be unreliable and thus should be discarded. This effectively makes the number of bins from which acoustic information is useful equal to 34 .

A current rose of current velocities averaged over the mentioned 34 bins is presented in Figure 6, and Figure 7 exhibits box plots of current speeds from each of the two metre ADCP bins.

An analysis of the depth-averaged currents suggests that west-southwesterly currents were dominant over the monitoring period.

Current roses for each of the instrument bins were also plotted (not presented here); the roses suggested some layering of the water column at the site. For instance, there were higher percentages of north-northwesterly and north-westerly currents within the near seabed water layer, up to the instru- ment bins 7 and 8, which are located around $20-22 \mathrm{~m}$ from the seabed, or at around $60 \mathrm{~m}$ depth.

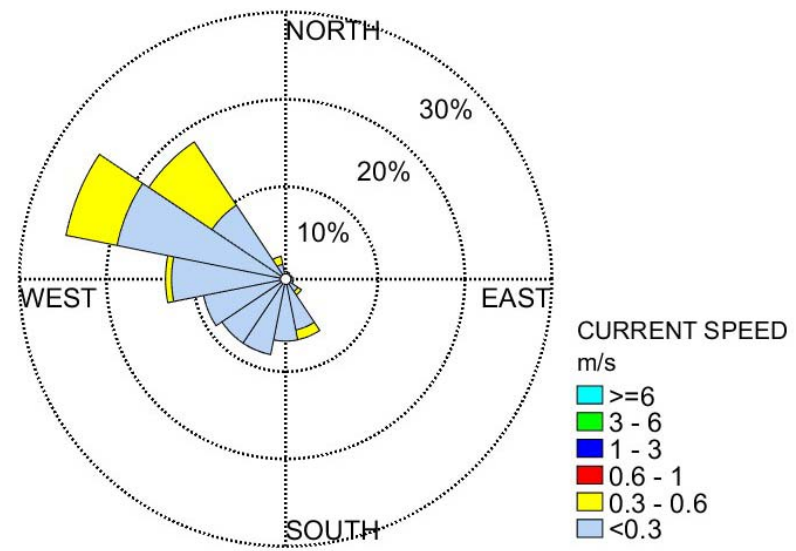

Figure 6 - Current rose plot representing averaged current velocities, from near seabed (Bin 1) through to near water surface (Bin 34)

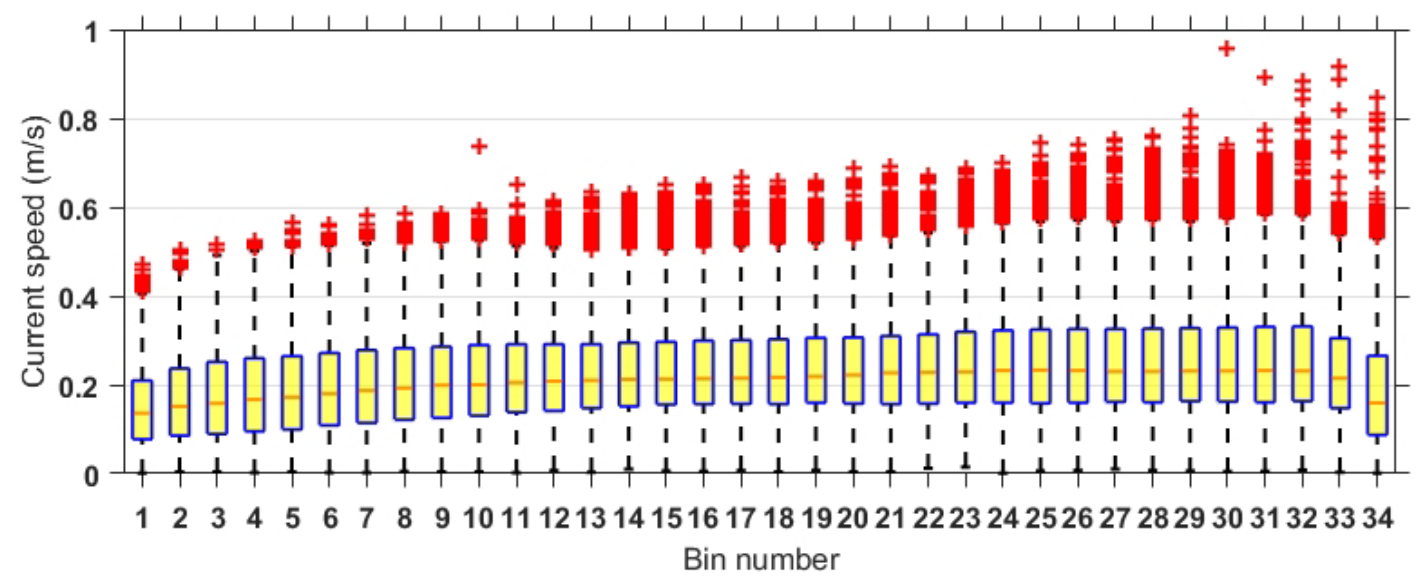

Figure 7 - Current speed for each of ADCP bins, from near seabed (Bin 1) through to near water surface (Bin 34) 
Above that depth, west-northwesterly currents were dominant.

Figure 7 shows that the median current speeds were within $0.15-0.25 \mathrm{~m} / \mathrm{s}$. The slowest currents were observed near the seabed. The maximal current speeds were consistently increasing throughout water column, from $0.5 \mathrm{~m} / \mathrm{s}$ near the seabed to around $0.8 \mathrm{~m} / \mathrm{s}$, and up to $1.0 \mathrm{~m} / \mathrm{s}$ in the near surface water layers.

Time series plots of current speeds and directions for each of the ADCP bins were also plotted (not presented here). A comparison of the plots with the sea level record presented in Figure 4 suggested that both current speeds and directions throughout the entire water column were affected by the dominant, periodic forcing in the area, which is barotropic, semi-diurnal tides.

It has been noticed however that stronger than usual winds of up to $10-12 \mathrm{~m} / \mathrm{s}$ observed on 27 , 28 and 29 April (see Figure 3 for the entire time series and Figure 8 for a zoomed representation) did have a defining impact on current speeds and directions on those days. The current speeds were higher than just from tidal forcing, which is more noticeable in the data from bin 34 sampled in the near water surface layer (Figure 9). This signal did propagate through the mid water column bin 17 (Figure 10), to the near seabed layer represented by bin 2 (Figure 11).

\subsection{Water temperature and salinity}

The distribution of water temperature and salinity with depth may reveal the presence of thermal stratification or halocline conditions in the water column. Both thermoclines and haloclines may lead to density layering within the water column, which in turn may limit mixing and thus affect plume dilution and transport. Therefore, monitoring of the above parameters contribute to in-depth understanding and better informed analysis in discharge plume transport studies.
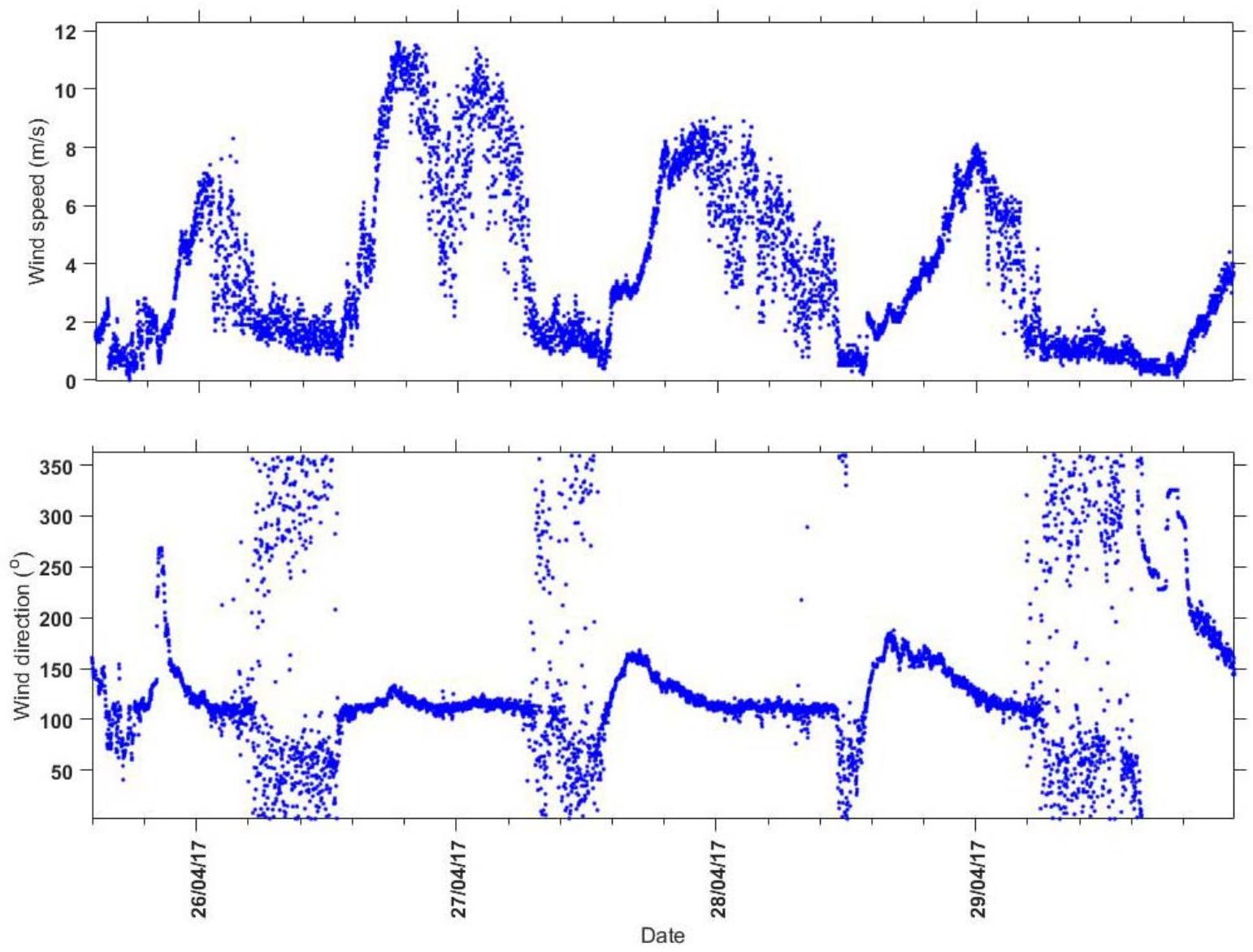

Figure 8 - Wind speeds (top panel) and directions (bottom panel), 26-29 April 2017 


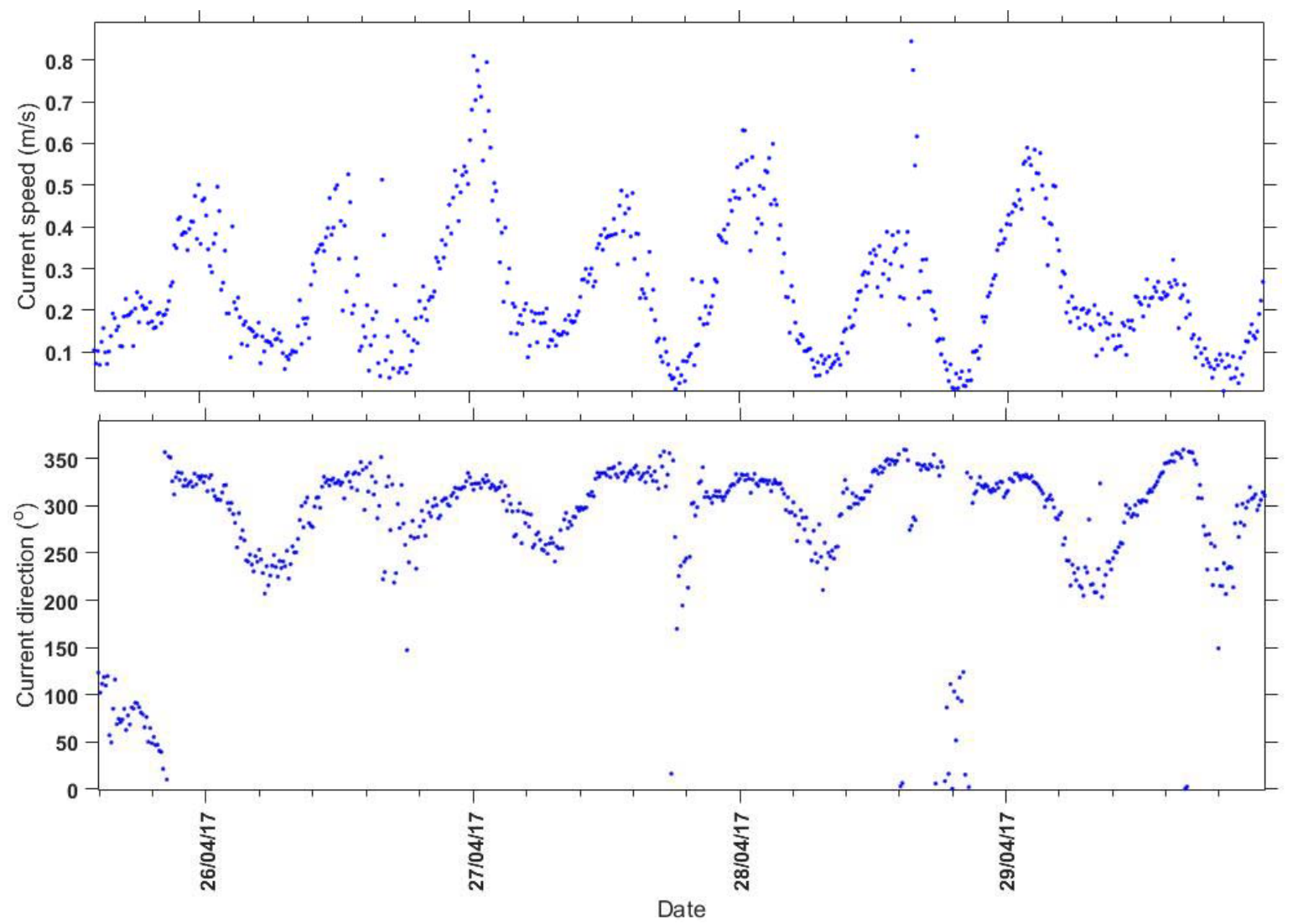

Figure 9 - Current speeds (top panel) and directions (bottom panel) from bin 34, 26-29 April 2017

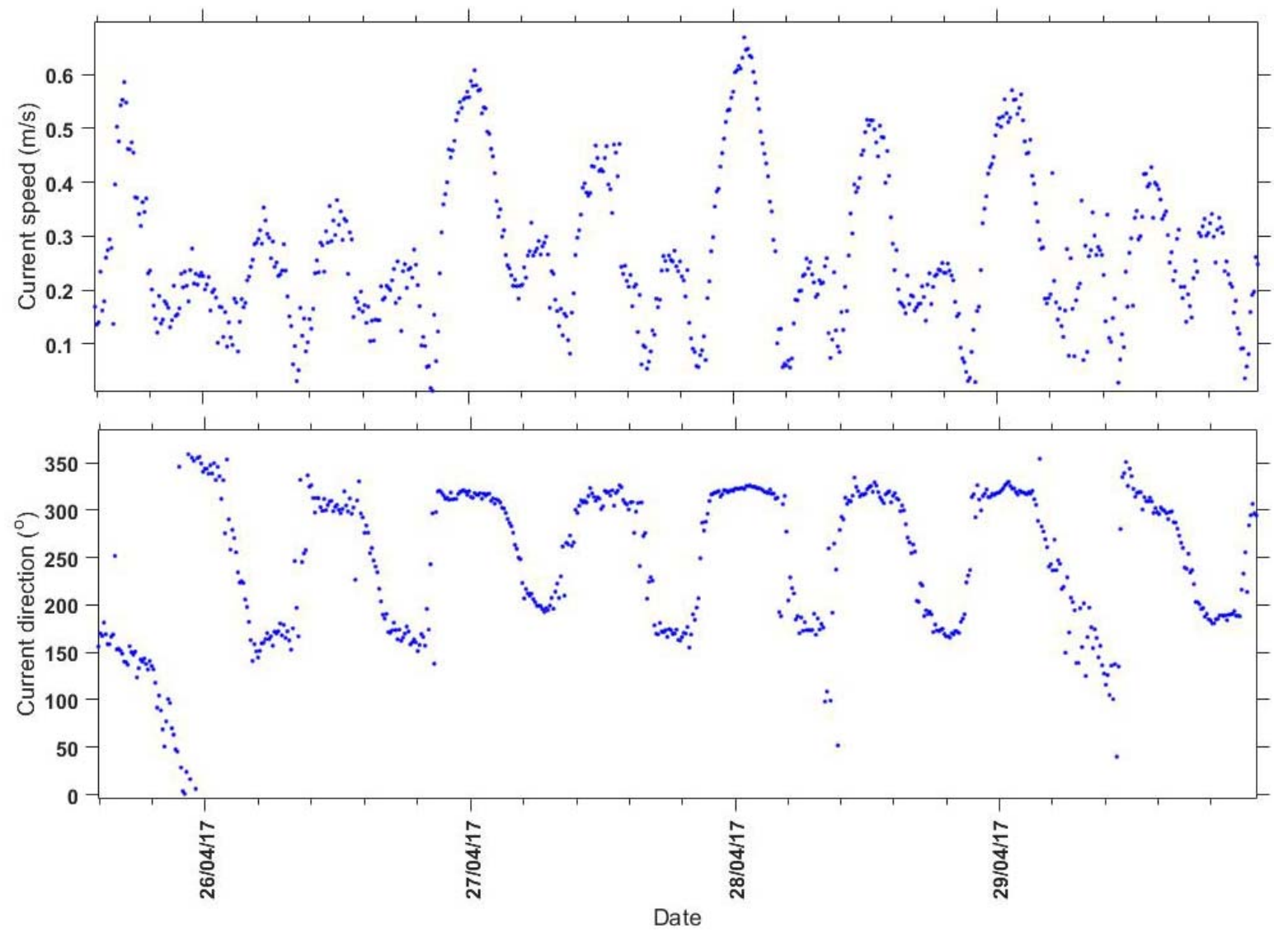

Figure 10 - Current speeds (top panel) and directions (bottom panel) from bin 17, 26-29 April 2017 


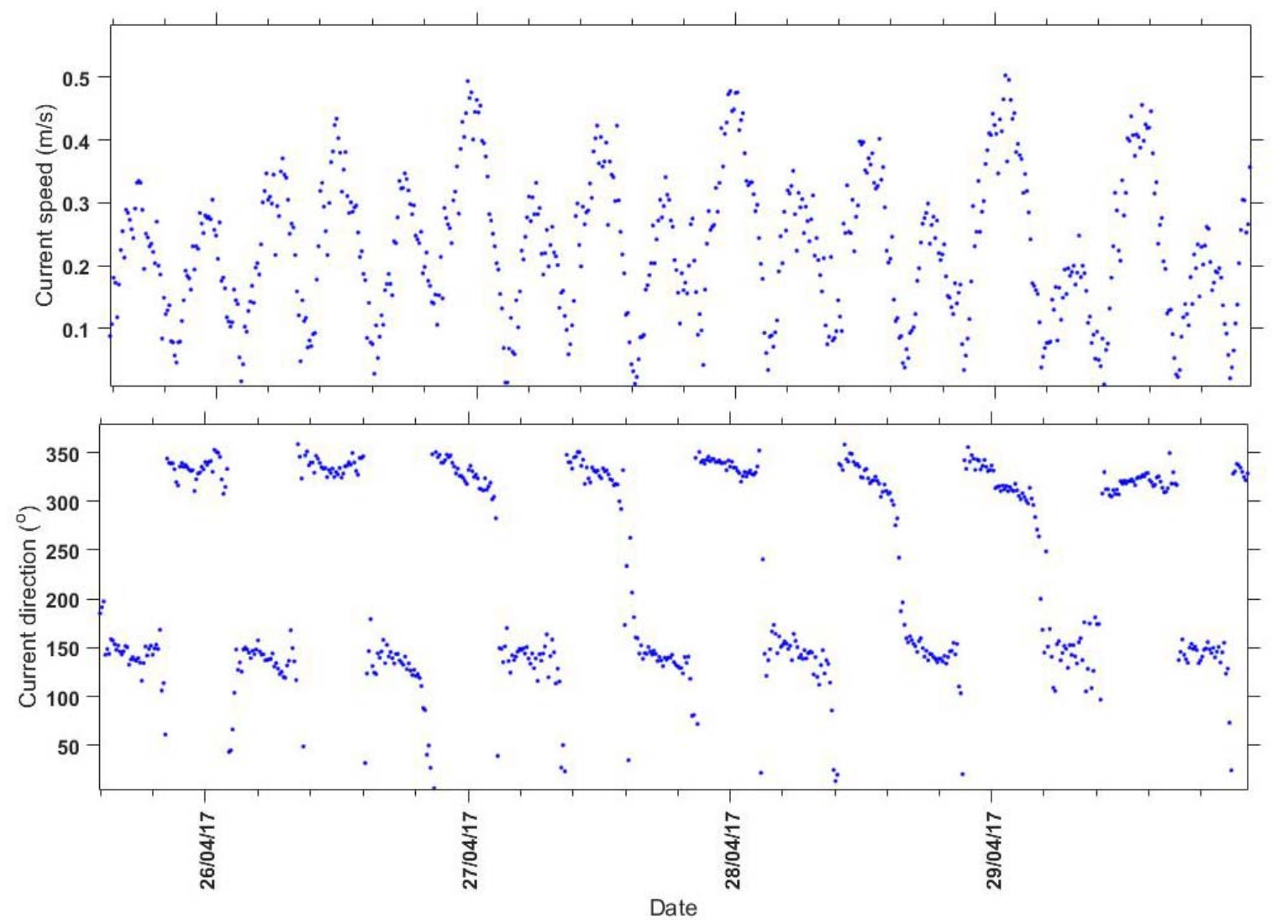

Figure 11 - Current speeds (top panel) and directions (bottom panel) from bin 2, 26-29 April 2017

There were a number of sensors mounted on the ROV, namely, temperature, salinity and pressure sensors. The pressure logs were processed and converted to depth. The distribution of water temperature and salinity with depth from the ROV multiple deployments over the monitoring period are presented in Figure 12.
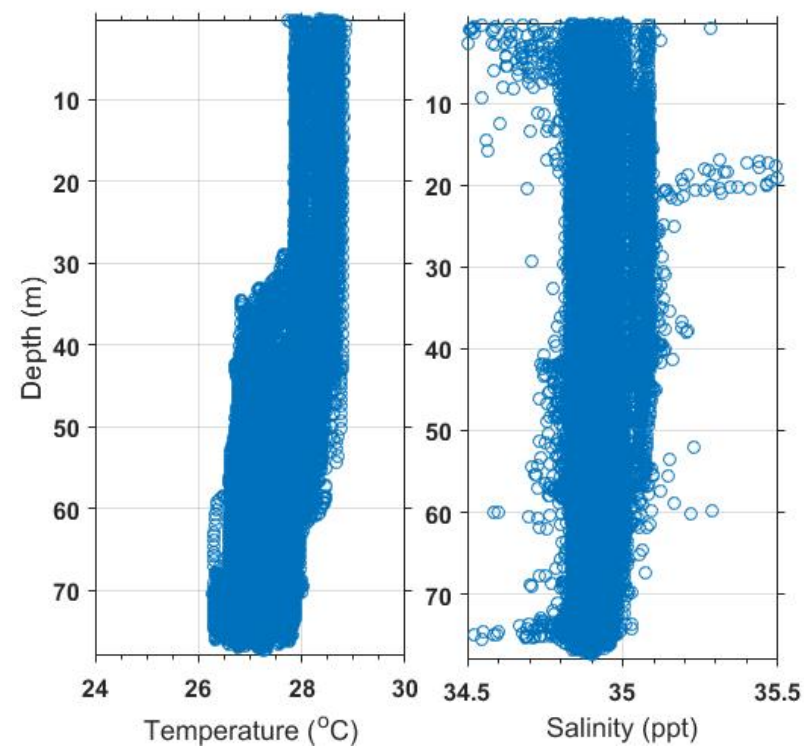

Figure 12 - Vertical distribution of temperature (left panel) and salinity (right panel) over monitoring period
An analysis of the temperature and salinity plots suggests that, based on the temperature distribution, there was water column layering observed over the monitoring period: from the water surface $(0 \mathrm{~m})$ to $30 \mathrm{~m}$ depth; from $30 \mathrm{~m}$ to $60 \mathrm{~m}$ depth; and from $60 \mathrm{~m}$ down to the seabed. The vertical distribution of salinity does not indicate the presence of layers though.

The above are confirmed by the box plots presented in Figure 13. There is around $0.6^{\circ} \mathrm{C}$ difference in water temperature among the layers. The median temperature of around $28.4^{\circ} \mathrm{C}$ within the 0-30 m layer is the highest among the layers, followed by the $27.8^{\circ} \mathrm{C}$ median within the $30-60 \mathrm{~m}$ layer, and the lowest median temperature of around $27.2^{\circ} \mathrm{C}$ within the near seabed layer.
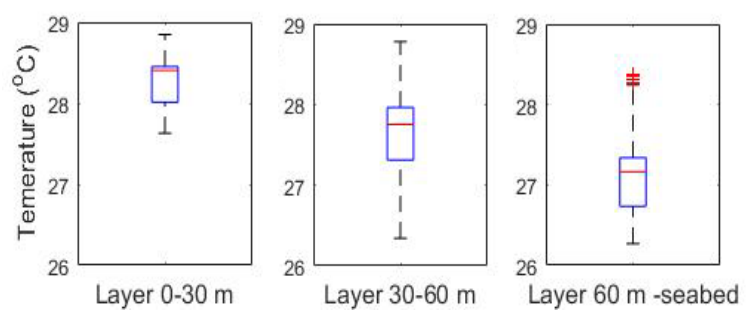

Figure 13 - Box plots of water temperature for three identified water layers 
The median salinity does not vary much among the layers though and stays near constant with the value around $34.9 \mathrm{ppt}$ (Figure 14).

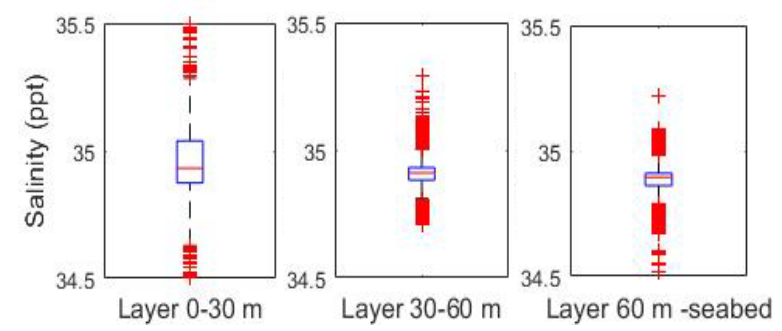

Figure 14 - Box plots of salinity for three identified water layers

\subsection{Water turbidity}

The variability of turbidity within the discharge plume was assessed using a turbidity sensor mounted on the ROV. There were 40 deployment logs processed and visualised; some sample timeseries of turbidity are presented in Figures 15-18.

An analysis of the obtained results suggested that the median values of turbidity were in general of few tenth of an NTU, with the top interquartile ranges within one NTU. The periods when the ROV was driven through the discharge plume are characterised by increased medians and a large number of outliers, with the registered turbidity values from a few NTU up to 450 NTU, which was set as the top limit for the turbidity logs.

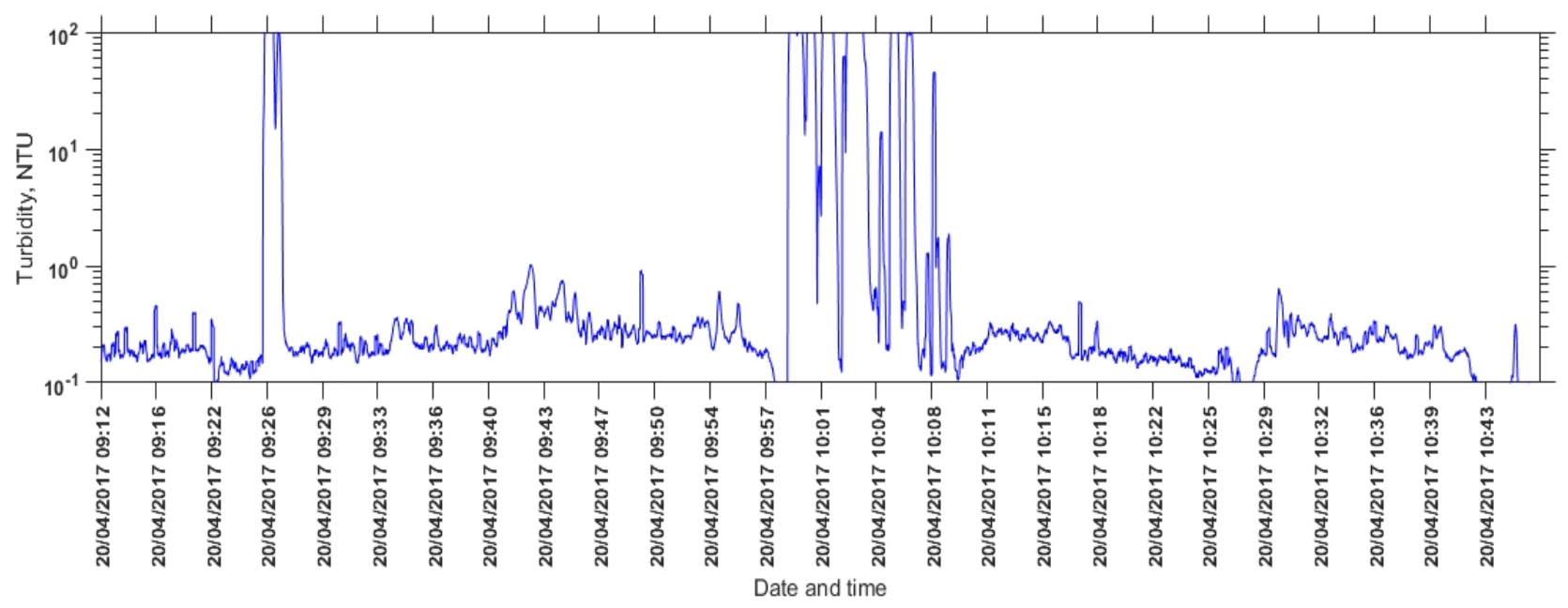

Figure 15 - Turbidity timeseries for mud release deployment of 20/04/2017

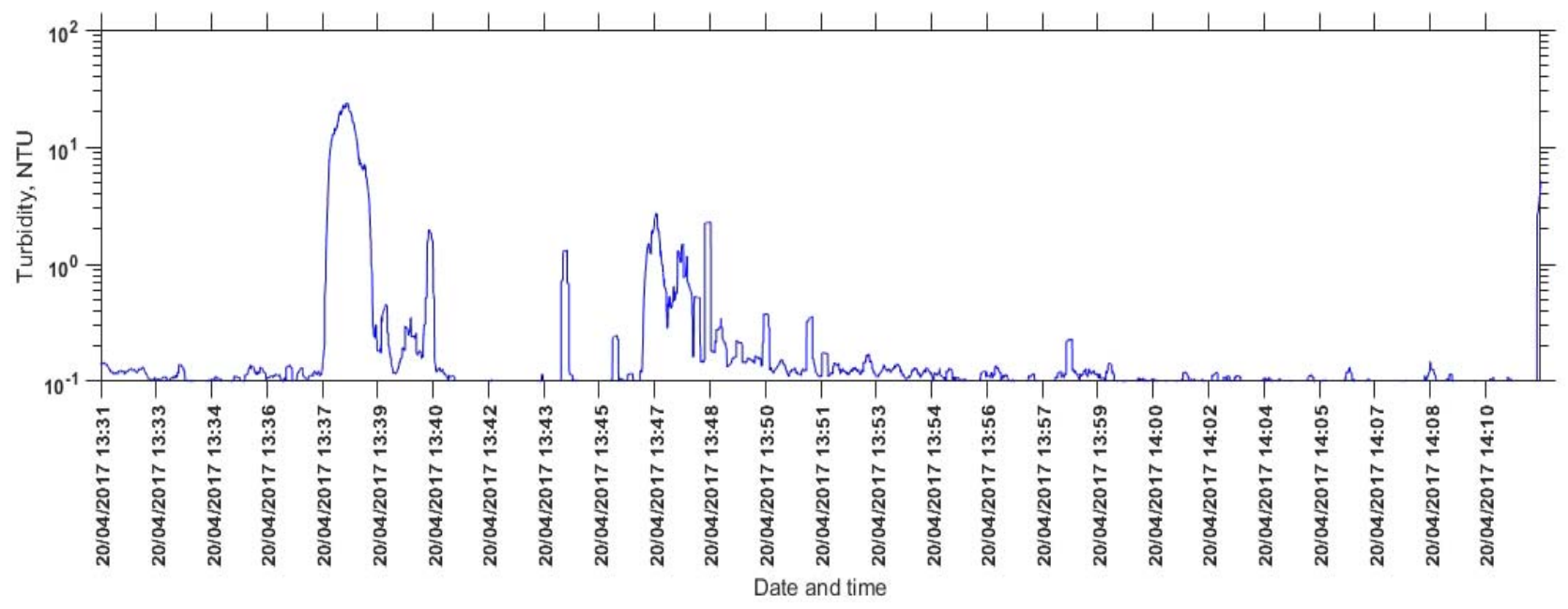

Figure 16 - Turbidity timeseries for post-release deployment of 20/04/2017 


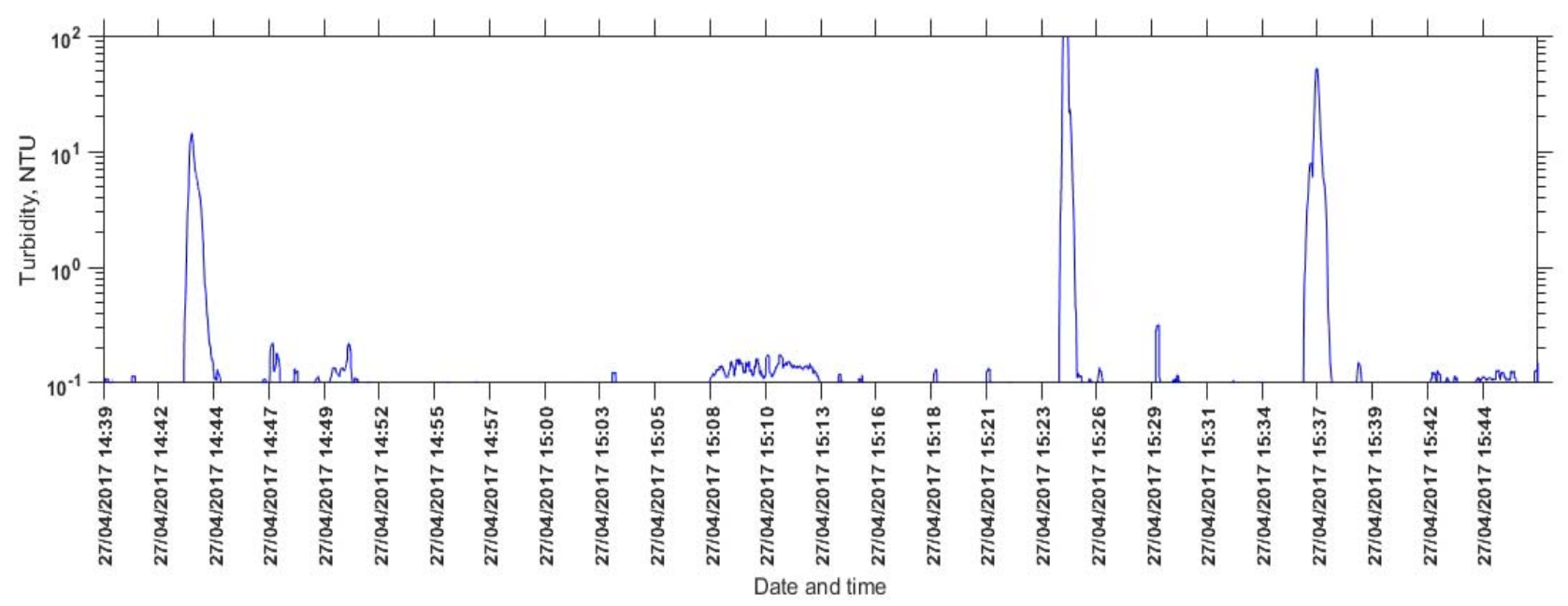

Figure 17 - Turbidity timeseries for deployment of 27/04/2017

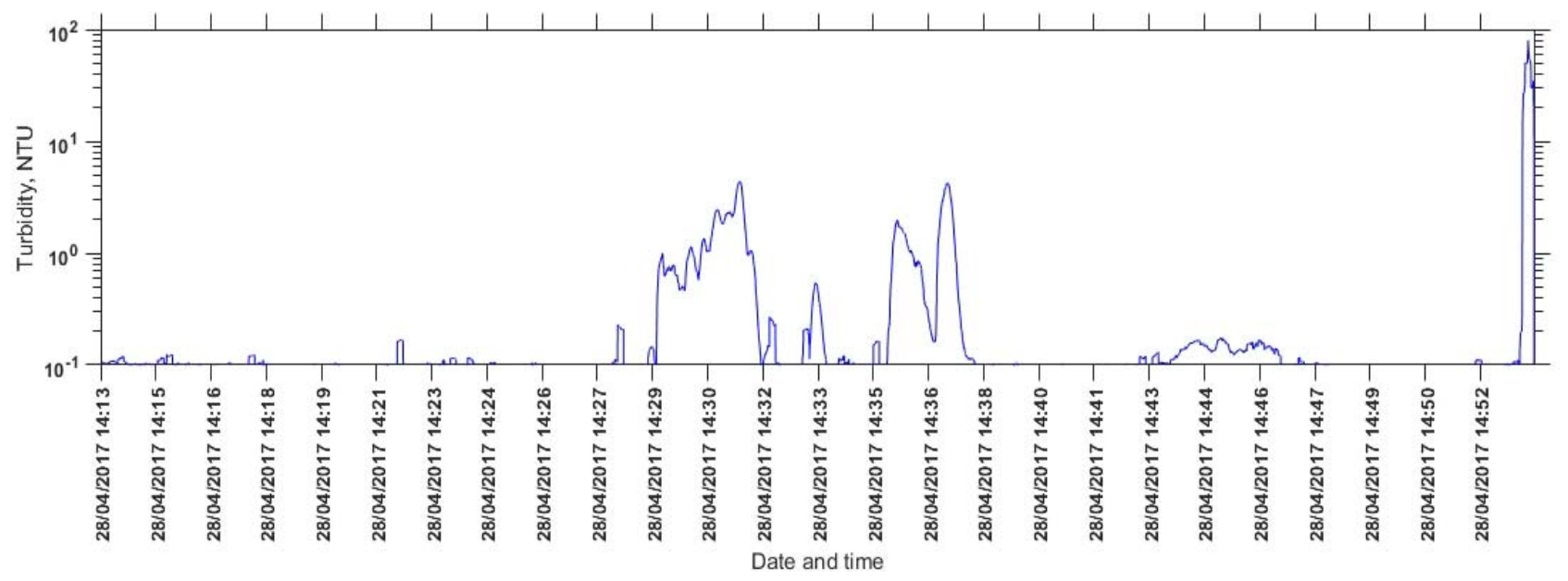

Figure 18 - Turbidity time series for deployment of 28/04/2017

\subsection{Acoustic echo intensity transects}

Acoustic echo intensity data in the marine environment may be collected using acoustic instruments, such as ADCPs. Acoustic echo intensity is measured in counts and is an indication of the strength of the returned signal. It is represented as a number between 0 (or 40 , which is the floor count for the acoustic noise) and 255.

The higher the number of counts the stronger is the return signal. The strength of the signal depends on the properties of the medium, e.g. water density, the presence of suspended particles in the water, and the presence of the density gradients, e.g. due to the signal interacting with water-air or water-seabed separating surfaces. For the purposes of the present study, the higher echo intensity zones would suggest the discharge plume passing over the ADCP, or the ROV passing through the plume.

Vertical profiles of suspended sediment concentrations may be assessed from acoustic echo inten- sity records, if suspended sediment samples are collected for the signal intensity calibration against the sampled concentrations (see e.g. [2, 4, 8] among many others). In this study, acoustic echo intensity data is considered in parallel with the turbidity timeseries, because these two parameters were recorded simultaneously during some of the ROV deployments. Note that the ADCP pressure sensor malfunctioned; it was therefore problematic sometimes to meaningfully differentiate the higher intensities from the enhanced sediment concentrations from the ones due to the presence of the water surface.

In total, there were 33 acoustic echo intensity transects collected by an ROV mounted ADCP, all processed and plotted for the purposes of this study; due to space limitations, only some selected plots are presented here. An analysis of the plots suggests that the echo intensity of the return acoustic signal did sometimes show higher number of counts in the first several bins (usually within a $10 \mathrm{~m}$ and up to 
$20 \mathrm{~m}$ range from the ADCP) at approximately the same times when higher turbidity values were logged. This was the case during the deployments on $20 / 04 / 2017$, where the peaking turbidity corresponds to the highest intensity counts logged around 9:26, from $9: 58$ to $10: 08$, from $13: 38$ to $13: 39$, and from 13:47 to 13:49 (Figures 15-Figures 16 and Figures 19-Figures 20 respectively). At other times, there was no obvious relation between the two parameters; for instance, the high number of echo intensity counts over several periods from 14:40 to $15: 40$ on $27 / 04 / 2017$ does not correspond to high turbidity records (Figure 21 and Figure 17 respectively). There also were cases when part-time there was no clear correspondence (from 14:23 to 14:26 on 28/04/2017) but then a correspondence seems appearing later (from 14:29 to $14: 36$ on 28/04/2017), all within the same timeseries and transect deployment records, see Figure 18 and Figure 22 respectively.

\section{DISCUSSION}

During the austral autumn and winter months, from April and May and through to August, winds over the project area are from various directions from east through south to west, with eastsoutheaserlies (the so called "south-east trade winds", see e.g. $[5,10])$ becoming dominant. This is well aligned with the general understanding of wind climatology of the area, and may indicate that any discharged material from the project site may be transported towards the sensitive habitat.

Importantly, stronger than usual winds of up to 10-12 m/s observed on 27, 28 and 29 April did have a defining impact on current speeds and directions on those days, with the current speeds being higher than just from tidal forcing. This is a very important deliberation for the present study, because, as Figure 8, Figure 9, Figure 10 and Figure 11 demonstrate, the winds on these occasions were from eastsoutheast and south-east, pushing water towards north-west, i.e. in the direction of sensitive habitat, with higher than usual speeds. Therefore, such wind events may result in impacts on the habitat from sediment plums discharged at the drilling location.

Nevertheless, the presented and analysed results in terms of sea levels and current velocities suggest that the hydrodynamics in the project area are dominated by semi-diurnal tides within mesotidal range.

Both current velocity and water temperature data over the monitoring period indicated the presence of three layers within the water column over the project site.

An analysis of the data suggests that the nearsurface, $30 \mathrm{~m}$ thick water layer with stronger currents and higher temperatures may be formed by the impact of wind on the water surface and solar irradiation and water heating propagating down to $30 \mathrm{~m}$ depth, and even deeper at some occasions.

The near-seabed, $20 \mathrm{~m}$ thick water layer may have slower currents due to the bottom friction, and lower temperatures due to the relative remoteness from the source of heat, the Sun, compared to the near water surface layer.

The middle layer does not appear to be affected by either the surface or seabed forcing, and thus demonstrates slightly different characteristics from those two layers in terms of both currents and temperature.

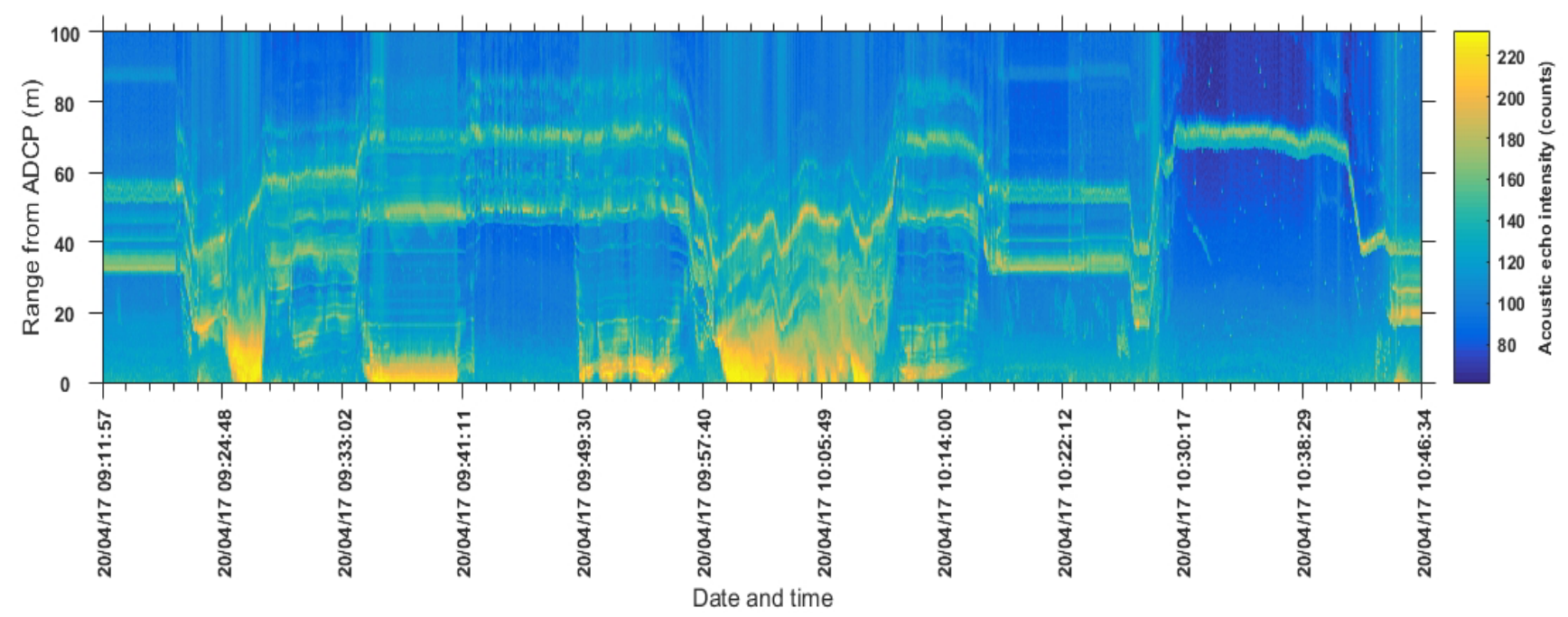

Figure 19 - Acoustic echo intensity for mud release deployment of 20/04/2017 


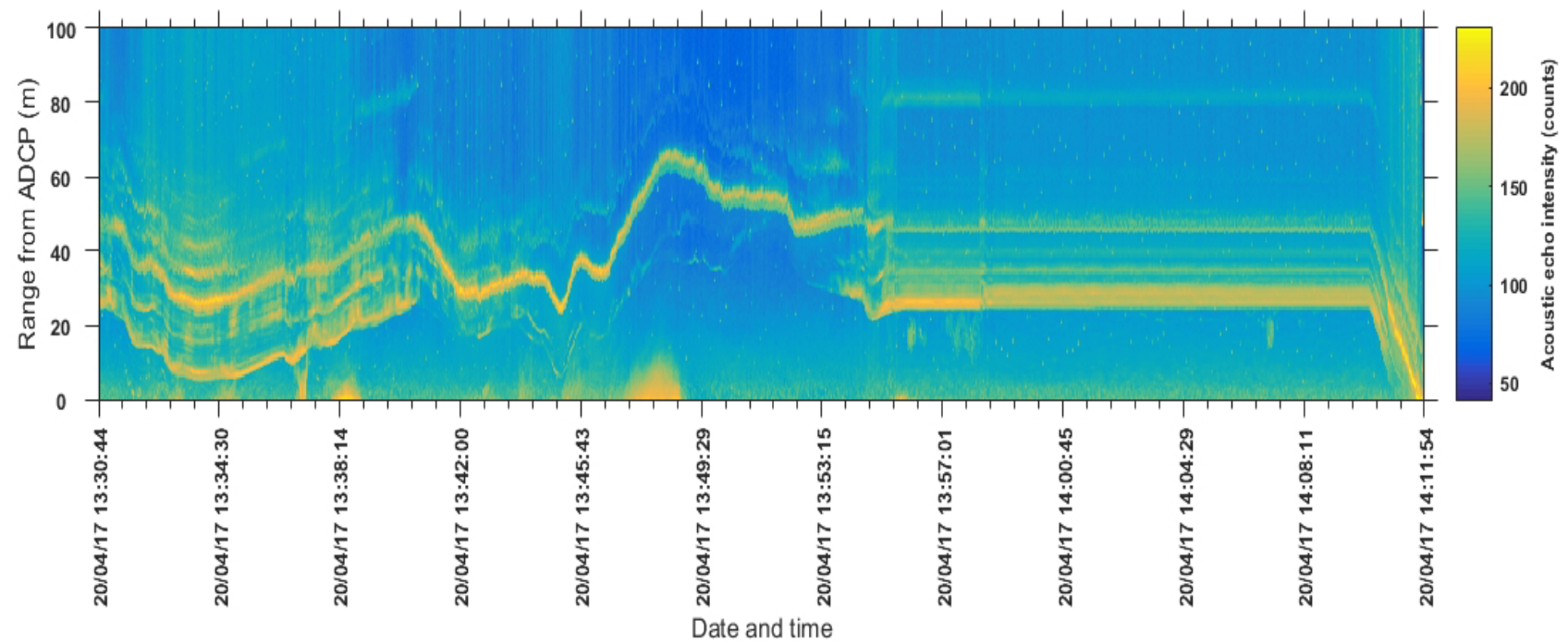

Figure 20 - Acoustic echo intensity for post-release deployment of 20/04/2017



Figure 21 - Acoustic echo intensity for deployment of 27/04/2017

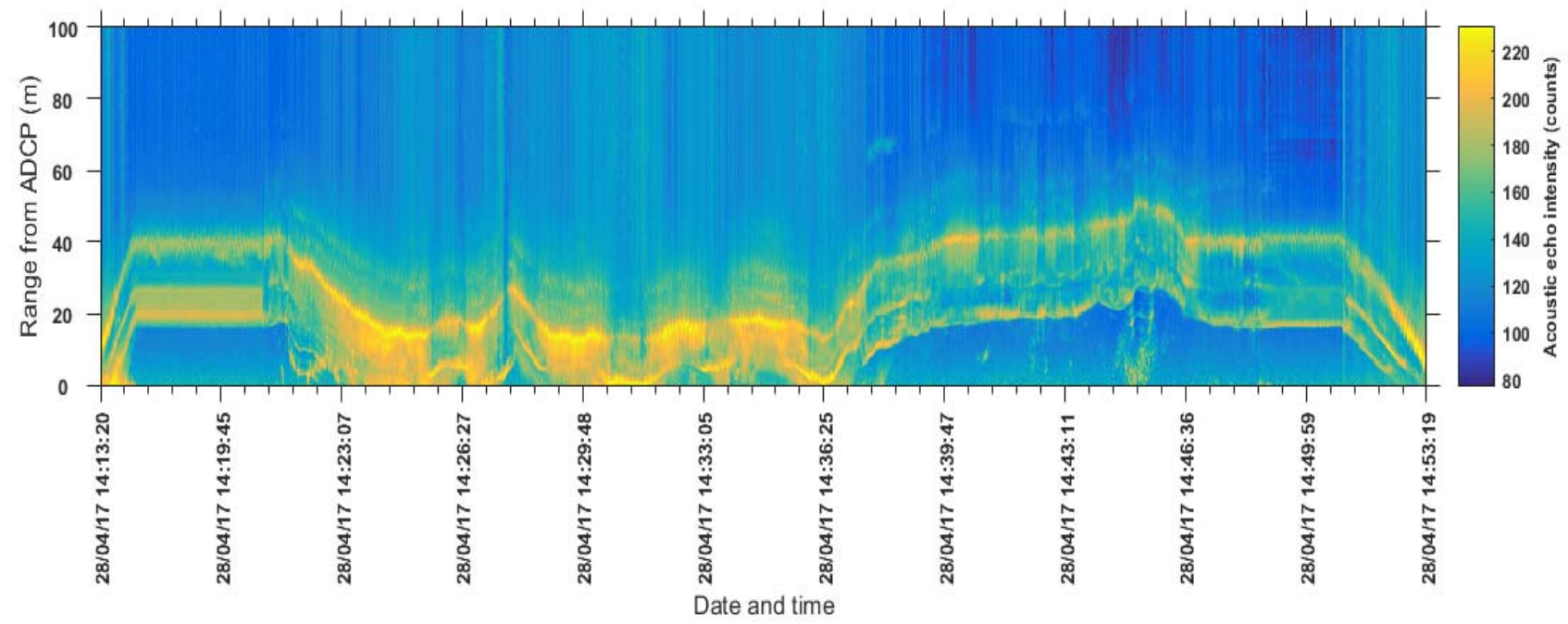

Figure 22 - Acoustic echo intensity for deployment of 28/04/2017 
The water salinity was rather homogenous throughout the entire water column, which is an indication that evaporation did not play a significant role in the area over the monitoring period. This may also be an implicit indication that the oceanographic processes in the area are dominated by the tidal forcing, and the entire water layer would be moving as one most of the time.

In terms of inconsistencies in the behaviour of the monitored turbidity and acoustic echo intensity, this type of irregular behaviour of two independent parameters (one from an optical instrument and another one from an acoustic instrument) may be an indication that the interrelationship between the two parameters is non-linear; this is assuming that each of these instruments performed well and logged data consistently, without malfunction or gaps in the records.

\section{CONCLUDING REMARKS}

An analysis of the wind conditions for the monitoring period suggested the winds were from various directions, with up to $40-45 \%$ of winds from eastsoutheast through to south-southeast. The results suggested that there were several instances when 10$12 \mathrm{~m} / \mathrm{s}$ winds from the south-easterly quadrant lasted for up to a day, which may be affecting patterns of transport of the discharged plums/material within the project area.

An analysis of the sea level registrations suggested semi-diurnal tides with the maximal tidal range of $3.1 \mathrm{~m}$ over the monitoring period.

Current data suggested the presence of a few layers: there were higher percentages of northnorthwesterly and north-westerly currents within the near seabed water layer, up to around $60 \mathrm{~m}$ depth, and dominant west-northwesterly currents above that depth. The maximal current speeds were consistently increasing throughout water column, from $0.5 \mathrm{~m} / \mathrm{s}$ near the seabed to around $0.8 \mathrm{~m} / \mathrm{s}$, and up to $1.0 \mathrm{~m} / \mathrm{s}$ near the water surface. The data suggested that, at the site, both current speeds and directions throughout the entire water column are affected by the semi-diurnal tides.

An analysis of the water temperature monitoring data confirmed that there was water column layering observed over the monitoring period, with three layers present vertically. The vertical distribution of salinity did not indicate the same layering, which may be another indicator of the area being dominated by mesotides, and suggests that evaporation over the monitoring period was not significant.

The median values of logged turbidity were in general around a few tenth of an NTU, with the top interquartile ranges within one NTU; the periods of passing through the discharge plume were characterised by increased medians and a large number of outliers, with the registered turbidity values from a few NTU up to 450 NTU.

Inter-comparisons of the acoustic echo intensity with the turbidity logs did sometimes demonstrate a good correspondence between the higher intensity counts and turbidity records, which would suggest the presence of the discharge plume passing over the instruments. At other times, however, there was no obvious relation between the two parameters. This may be an indication that the interrelationship between the two parameters is not linear; this is assuming that the acoustic and optical instruments performed and logged data consistently, without malfunction or gaps in the records.

\section{ACKNOWLEDGMENTS}

The offshore project operator is acknowledged for providing the oceanographic and water quality data used in this study.

Australian Institute of Marine Science is acknowledged for making available the necessary for this study research staff for completing technical tasks, as well as office space, hardware and software.

\section{REFERENCES}

1. D'Adamo, N., Fandry, C., Buchan, C. \& et al. (2009). Northern sources of the Leeuwin Current and the "Holloway Current" on the North West Shelf. Journal of the Royal Society of Western Australia, 92(2), pp. 53-66.

2. Deines, K.L. (1999). Backscatter estimation using broadband acoustic Doppler current profilers. Proceedings of the IEEE Sixth Working Conference on Current Measurement, March 11-13. San Diego, CA, USA, pp. 249-253.

3. Falkner, I, Whiteway, T., Przeslawski, R. \& Heap, A. (2009). Review of ten key ecological features (KEFs) in the Northwest Marine Region. Geoscience Australia Record 2009/13. Geoscience Australia, Canberra.

4. Gartner, J.W. (2004). Estimating suspended solids concentrations from backscatter intensity measured by acoustic Doppler current profiler in San Francisco Bay, California. Marine Geology, 211, pp. 169-187. doi:10.1016/j.margeo.2004.07.001.

5. Holloway, P.E.\& Nye, H.C. (1985). Leeuwin Current and wind distributions on the southern part of the Australian North West Shelf between January 1982 and July 1983. Australian Journal of Marine and Freshwater Research, 36, pp. 123-137.

6. Langtry, S., Rayson, M., Makarynskyy, O. et al. (2009). Optimal selection of sediment disposal sites in open coast locations. Coasts and Ports in a Dynamic Environment, 1618 September. Wellington, New Zealand, 7p, CD-ROM. 
7. Makarynskyy, O., Langtry, S., Zapata, M. et al. (2010). Validations of hydrodynamic, wave and dredging simulations in nearshore environments. In: Spaulding M.L. (ed.). Estuarine and Coastal Modeling. ASCE Publications, pp. 547-565.

8. Makarynskyy, O. \& Makarynska, D. (2015). Monitoring ocean water parameters in a meso-tidal harbour: a recent example from Queensland. Proceedings of the New South Wales Coastal Conference 2015. Forster, NSW, 6p, USB.

9. Makarynska, D. \& Makarynskyy, O. (2017). Hydrodynamic and sediment plume modelling in a macro-tidal estuary. Coasts\&Ports 2017, 21-23 June. Cairns, Australia, 6p, USB.
10. Pearce, A., Hart, A., Murphy, D. et al. (2015). Seasonal wind patterns around the Western Australian coastline and their application in fisheries analysis. Fisheries Research Report No.266. Department of Fisheries, Western Australia.

11. Rayson, M., Langtry, S. \& Makarynskyy, O. (2007). Methods for dredge modelling with the inclusion of sediment resuspension. Proceedings of the II International Conference on Natural Environment-2007: Critical Problems of Ecology and Hydrometeorology; Merging of Education and Science, 26-28 September. Odesa, Ukraine.

\title{
КОМПЛЕКСНИЙ МОРСЬКИЙ МОНІТОРИНГ БУРОВИХ СКИДІВ ПІД ДІЄЮ МЕЗОПРИПЛИВІВ
}

\section{Олег Макаринський, Діна Макаринська}

\author{
Metocean Dynamic Solutions, 9 Seale Street, Fannie Bay, 0820 NT, Australia, \\ makarynskyy@outlook.com, https://orcid.org/0000-0002-0505-5882
}

На північно-західному шельфі австралійського континенту виконується ряд промислових проектів 3 розвідки і видобутку вуглеводнів. Цей шельф являє собою різноманітну i важливу морську екосистему 3 численними глобально значущими мілководними кораловими рифами і морськими охоронюваними районами, які мають життєво важливе значення для виживання видів, яким загрожує зникнення.

Деякі із згаданих розвідувальних і видобувних робіт, таких як морське буріння, можуть бути дозволені в межах кількох кілометрів від чутливих місць існування, які знаходяться поблизу району видобутку. У деяких випадках середовища існування можуть бути представлені зануреними екологічними системами 3 високим біорізноманіттям i, отже, високою екологічною/ екосистемною цінністю через наявність бентосної біоти та/або рибних угрупувань.

В межах програми екологічної оцінки наслідків промислової діяльності деякі оператори морських розвідувальних робіт вивчають вплив бурових скидів на морське середовище. У цьому дослідженні розглядаються такі оцінки. Для оцінки був концептуально розроблений новий комплексний підхід до морського моніторингу. Потім програма моніторингу була виконана в польових умовах з використанням обладнання, встановленого на дні, і підводного апарату з дистанційним управлінням зі змонтованими на ньому датчиками.

Дане дослідження присвячене аналізу вітрових умов в зоні проекту, рівня моря, течії, спостережень за температурою води, солоністю, каламутністю і інтенсивністю акустичного відлуння протягом декількох етапах бурових робіт, у той час як буровий шлам і буровий розчин скидалися в товщу води.

Спостереження за вітром в період осінніх місяців (квітень-травень) Південної півкулі показали переважання східно-південно-східних вітрів, що добре узгоджується із загальним розумінням вітрового режиму району. Важливо відзначити, що сильніший, ніж зазвичай, вітер може мати визначальний вплив на швидкості і напрям течій, які посилюються такими вітрами. У цих випадках забруднена скидами водна маса може наближатися до чутливого середовища існування, присутнього в цьому районі. Однак, наразі у динаміці вод в зоні проекту переважають півдобові припливи. Як вертикальна швидкість потоку, так і розподіл температури води вказували на наявність трьох шарів в товщі води над проектною ділянкою. Вертикальний розподіл солоності води був досить однорідним у всьому шарі води.

Моніторинг каламутності 3 використанням оптичного приладу та за допомогою інтенсивності акустичного відлуння-сигналу, отриманого за допомогою АДВТ (акустичного допплерівського вимірювача течії), показав, що відстеження шлейфів підвищеної каламутності за допомогою дистанційно керованого підводного обладнання є життєздатним методом, який може бути реалізований в інших місцях. Такі незалежні параметри, проте, потребують ретельного перехресного калібрування і взаємної валідації для повного розуміння результатів. 
Ключові слова: континентальний шельф, буріння, шлами, бурові розчини, шлейф, каламутність, підводний апарат з дистанційним керуванням, розшарування товщі води, акустичний допплерівській вимірював течії, інтенсивність відлуння

\title{
КОМПЛЕКСНЫЙ МОРСКОЙ МОНИТОРИНГ БУРОВЫХ СБРОСОВ ПОД ВОЗДЕЙСТВИЕМ МЕЗОПРИЛИВОВ
}

\author{
Олег Макаринский, Дина Макаринская \\ Metocean Dynamic Solutions, 9 Seale Street, Fannie Bay, 0820 NT, Australia, \\ makarynskyy@outlook.com, https://orcid.org/0000-0002-0505-5882
}

На северо-западном шельфе австралийского континента выполняется ряд промышленных проектов по разведке и добыче углеводородов. Этот шельф представляет собой разнообразную и важную морскую экосистему с многочисленными глобально значимыми мелководными коралловыми рифами и морскими охраняемыми районами, которые имеют жизненно важное значение для выживания видов, которым грозит исчезновение.

Некоторые виды упомянутых работ по разведке и добыче углеводородов, такие как морское бурение, могут быть разрешены в пределах нескольких километров от чувствительных к их воздействию мест обитания, расположенных вблизи района добычи. Места обитания в некоторых случаях могут быть представлены экосистемами мелководья с высоким биоразнообразием и, таким образом, высокой экологической / экосистемной ценностью из-за присутствия биоты бентоса и/или рыбных сообществ.

В рамках программы экологической оценки последствий промышленной деятельности некоторые операторы морских разведочных работ изучают влияние буровых сбросов на морскую среду. В этом исследовании рассматриваются такие оценки. Для оценки был концептуально разработан новый комплексный подход к морскому мониторингу. Затем программа мониторинга была выполнена в полевых условиях с использованием оборудования, установленного на дне, и подводного аппарата с дистанционным управлением с установленными на нем датчиками.

Данное исследование посвящено анализу ветровых условий в зоне проекта, уровня моря, течений, наблюдений за температурой воды, соленостью, мутностью и интенсивностью акустического эха на нескольких этапах буровых работ, в то время как буровой шлам и буровой раствор выбрасывались в толщу води.

Наблюдения за ветром в период осенних месяцев (апрель-май) Южного полушария показали преобладание восточно-юго-восточных ветров, что хорошо согласуется с общим пониманием ветрового режима района. Важно отметить, что более сильный, чем обычно, ветер может оказывать определяющее влияние на скорости и направления течений, усиливая их. В этих случаях загрязненная сбросами водная масса может приближаться к чувствительной среде обитания в этом районе. Однако, как правило, в динамике вод в зоне проекта преобладают полусуточные приливы. Как вертикальная скорость потока, так и распределение температуры воды указывали на наличие трех слоев в толще воды над проектным участком. Вертикальное распределение солености воды было довольно однородным по всей толще воды.

Мониторинг мутности с использованием оптического прибора и интенсивности акустического эхо-сигнала при помощи АДИТ (акустического доплеровского измерителя течения) показал, что отслеживание шлейфов мутности с помощью подводного аппарата является жизнеспособным методом, который может быть реализован в других местах. Такие независимые параметры, тем не менее, нуждаются в тщательной перекрестной калибровке и взаимной валидации для полного понимания результатов.

Ключевые слова: континентальный шельф, бурение, шламы, буровые растворы, шлейф, мутность, подводный аппарат с дистанционным управлением, расслоение толщи воды, акустический доплеровский измеритель течений, интенсивность эха.

Подання до редакиіï: 18. 04. 2019 